\title{
Diagnostic pitfalls of hyperprolactinemia: the importance of sequential pituitary imaging
}

\author{
Tomohiro Kawaguchi ${ }^{1}$, Yoshikazu Ogawa ${ }^{1 *}$ and Teiji Tominaga ${ }^{2}$
}

\begin{abstract}
Background: The purpose of this study is to confirm whether the serum prolactin cut-off value is definitive to distinguish prolactinoma and non-functioning pituitary adenoma with hyperprolactinemia. We retrospectively reviewed patients with non-functioning pituitary adenoma, including gonadotroph cell adenoma, null cell adenoma and prolactinoma who were surgically treated at Kohnan hospital between June 2005 and March 2012. The patients without endocrinological/neurological symptom and with the tumor larger than $40 \mathrm{~mm}$ in diameter were excluded. According to previously reported cut-off value of serum prolactin, mild hyperprolactinemia, which is considered non-definitive (border zone) concentration between prolactinoma and non-functioning pituitary adenoma, were defined as $90-200 \mathrm{ng} / \mathrm{ml}$. Ninety-five prolactinoma patients and 212 patients with non-functioning pituitary adenoma were analyzed. The serum prolactin concentration, tumor size, and clinical characteristics were statistically compared.

Results: Receiver operating characteristic (ROC) curve analysis was performed, indicating that cut-off value of serum prolactin concentration to distinguish between non-functioning pituitary adenoma and prolactinoma was $38.6 \mathrm{ng} / \mathrm{ml}$. Although it was statistically good accuracy (the area under the curve; 0.96, sensitivity; 0.99 and specificity; 0.81 ), the result did not fit the clinical situation as many false-positive cases (40 of 212, 18.9\%) were included. Among them, mild hyperprolactinemia were shown in 9 (4.2\%) and 53 (55.8\%) non-functioning pituitary adenoma and prolactinoma, respectively. Four of 9 border zone patients with non-functioning pituitary adenoma were initially treated with dopamine agonists. Sequential head magnetic resonance imaging revealed no tumor shrinkage in all of them despite serum prolactin concentration was decreased. Surgery was chosen for them 24.6 months in average after the introduction of medication.

Conclusions: Non-negligible number of patients with non-functioning pituitary adenoma presented unexpectedly high concentration of prolactin, fraught with a potential risk of misdiagnosis. While this equivocal population is not the majority, the prolactin cut-off value is not safely applicable. Especially for the patients with border zone prolactin concentration, meticulous follow up with sequential pituitary imaging is important.
\end{abstract}

Keywords: Dopamine agonist, Hyperprolactinemia, Infertility, Magnetic resonance imaging, Non-functioning pituitary adenoma

\section{Background}

Hyperprolactinemia has been associated with a large number of etiologies, such as certain medication, autoimmune disease, and sellar tumors. Pituitary adenoma is one of the most frequent causes of hyperprolactinemia, and prolactinoma accounts for a high proportion of hyperprolactinemia due to prolactin overproduction and oversecretion.

\footnotetext{
* Correspondence: yogawa@kohnan-sendai.or.jp

'Department of Neurosurgery, Kohnan Hospital, 4-20-1 Nagamachi Minami, Taihaku-ku, Sendai, Miyagi 982-8523, Japan

Full list of author information is available at the end of the article
}

Non-functioning pituitary adenoma is another etiology of hyperprolactinemia, which is induced by compression of the pituitary stalk.

Medical treatment with dopamine agonists (DAs) is highly effective for most cases, so that is widely accepted as the first line of treatment for hyperprolactinemia. In spite of the strong suppression of serum prolactin level, DAs usage has several disadvantages when used for patients with prolactinoma. Intolerance and residence have been reported in some patients [1,2], and DAs are reported as a potential predisposing factor for pituitary 
apoplexy [3]. For the pregnant patients, less data is available about the effects of continuous DAs usage on fetal development $[4,5]$. Furthermore, DAs can normalize the serum prolactin level in patients with non-functioning pituitary adenoma presented with hyperprolactinemia by inhibition of the normal pituitary function, but there is no chance for tumor regression. So surgical treatment can be a considerable treatment option for some patients with large pituitary adenoma presented with hyperprolactinemia.

To decide the treatment options, discrimination of the cause for hyperprolactinemia is important. Small tumors presented with hyperprolactinemia could be considered prolactinoma in majority of the cases, so that it is not so difficult making correct diagnosis. However, differential diagnosis of large non-functioning pituitary adenoma and prolactinoma is sometimes very difficult despite several endocrinological loading tests and radiographical assessments have been evaluated [6]. Although recent reports indicated the endocrinological discrimination of non-functioning pituitary adenoma from prolactinoma, the cut-off value of serum prolactin concentration between them varied widely from 94 to $200 \mathrm{ng} / \mathrm{ml}$ and there are no definitive diagnostic criteria [6-8].

In this study, we retrospectively reviewed the patients with prolactinoma and non-functioning pituitary adenoma presented with hyperprolactinemia to confirm whether the serum prolactin cut-off value is definitive to distinguish them. The characteristics of clinical course and management for these patients were discussed.

\section{Methods}

\section{Participants}

We retrospectively reviewed patients with non-functioning pituitary adenoma, including gonadotroph cell adenoma and null cell adenoma, and prolactinoma who were surgically treated at Kohnan hospital between June 2005 and March 2012. Most patients with prolactinomas were referred from the endocrinological or gynecological clinics. During this period, 724 cases were treated with transsphenoidal surgery, performed by single surgeon (Y.O.). Among them, 95 (13.1\%) patients with prolactinoma and 212 (29.3\%) patients with non-functioning pituitary adenoma were analyzed.

\section{Surgical indication for prolactinoma}

Surgery was indicated for the patients who required skull base reconstruction to prevent cerebrospinal fluid leakage, and who already presented severe visual disturbance. Patients with small tumor without endocrinological and neurological symptoms were not included. Otherwise, we propose both medical treatment and surgery as treatment options. The advantage and disadvantage of them were equivalently explained. Surgery was performed for patients who understood and chose surgical treatment by themselves. Informed consent was obtained from each patient or guardian on admission, and prior to surgery.

\section{Data collection}

The following variables were recorded in a database and analyzed: age, sex, histological diagnosis, pretreatment serum concentration of anterior pituitary hormones including prolactin, and the maximum diameter of the tumors. Normal range of serum prolactin concentration in our hospital was $4.29-13.69 \mathrm{ng} / \mathrm{ml}$ in men, 4.91 $29.32 \mathrm{ng} / \mathrm{ml}$ in premenopausal women, and 3.12 $15.39 \mathrm{ng} / \mathrm{ml}$ in postmenopausal women.

\section{Clinical management}

On admission, the general physiological examination and magnetic resonance (MR) imaging were performed and basal value of serum anterior pituitary hormones were examined prior to surgery in all patients. If patients had already treated with dopamine agonist, administration was stopped several weeks before the surgery. In such cases, preoperative highest value of serum prolactin was considered as the initial prolactin value. After required examination, transsphenoidal adenomectomy was performed and the surgical specimens were proceeded for histopathological examination. Pathology review was performed based on World Health Organization classification 2004 [9].

\section{Determination of the cut-off value of serum prolactin concentration and definition of border zone patients with mild hyperprolactinemia}

To identify the cut-off value of serum prolactin level, receiver operating characteristic (ROC) curve analysis was performed with JMP-pro software (SAS Institute Japan, Tokyo, Japan). According to the previous reports, mild hyperprolactinemia, which is considered non-definitive concentration between prolactinoma and non-functioning pituitary adenoma, were defined as $90-200 \mathrm{ng} / \mathrm{ml}$ $[8,10,11]$. The patients with serum prolactin concentration in this range were considered as border zone cases.

\section{Statistical analysis}

The means and standard deviations (SDs) for serum prolactin concentration was calculated and compared with Student's $t$-test or Fisher's exact test. Probability values $<0.05$ were considered statistically significant. SPSS software (IBM Japan, Tokyo, Japan) were used for statistical analyses. 
Table 1 Demographic characteristics of the total study population

\begin{tabular}{|c|c|c|c|c|}
\hline \multicolumn{2}{|c|}{ Characteristic } & \multirow{2}{*}{$\frac{\text { Non-functioning adenoma }}{23-80(60)}$} & \multirow{2}{*}{$\frac{\text { Prolactinoma }}{14-82(38)}$} & \multirow{2}{*}{$\frac{P \text { value }}{<0.001^{*}}$} \\
\hline Age, years old & Range (median) & & & \\
\hline \multirow[t]{2}{*}{ Sex } & Male (\%) & $98(46.2)$ & $20(21.1)$ & 0.05 \\
\hline & Female (\%) & $114(53.8)$ & 75 (78.9) & - \\
\hline Tumor size & Maximum Diameter $($ mean $\pm S D, m m)$ & $23.4 \pm 6.3$ & $15.4 \pm 9.0$ & $<0.001^{*}$ \\
\hline Serum prolactin concentration & $($ mean $\pm S D, n g / m l)$ & $28.4 \pm 32.1$ & $747.0 \pm 1548.9$ & $<0.001^{*}$ \\
\hline
\end{tabular}

*statistically significant.

SD, standard deviation.

\section{Results}

\section{Patient characteristics}

The characteristics of patients with non-functioning pituitary adenoma and prolactinoma were summarized in Table 1 . The age of patients with non-functioning pituitary adenoma was higher than with prolactinoma $(\mathrm{p}<$ 0.001 ). The tumor size of non-functioning pituitary adenoma was larger than prolactinoma $(\mathrm{p}<0.001)$. Preoperative serum prolactin concentrations was $28.4 \pm 32.1$ and $747.0 \pm 1548.9 \mathrm{ng} / \mathrm{ml}$ (mean $\pm \mathrm{SD}$ ) in patients with non-functioning pituitary adenoma and prolactinoma, respectively. There was statistically significant difference in the mean value of prolactin between the two groups $(\mathrm{p}<0.001)$.

\section{Serum prolactin concentration and patient distribution}

The patient distribution according to serum prolactin concentration was shown in Figures 1 and 2. In 212 patients with non-functioning pituitary adenoma, most patients presented between 10 to $20 \mathrm{ng} / \mathrm{ml}$ of serum prolactin concentration and the highest prolactin value was $284.9 \mathrm{ng} / \mathrm{ml}$ (Figure 1). In 95 patients with prolactinoma, most of them presented serum prolactin concentration around $100 \mathrm{ng} / \mathrm{ml}$ and 53 (55.8\%) of them presented the serum prolactin concentration less than $200 \mathrm{ng} / \mathrm{ml}$. Seventeen (18.0\%) patients presented the serum prolactin concentration over $1000 \mathrm{ng} / \mathrm{ml}$ resulting in raising the mean value (Figure 2).

\section{Determination of the cut-off value of serum prolactin concentration}

ROC curve analysis was performed for all cases (Figure 3). The area under the curve was 0.96, which indicated high accuracy of diagnostic value. According to this analysis, cut-off value of serum prolactin concentration to distinguish between non-functioning pituitary adenoma and prolactinoma was $38.6 \mathrm{ng} / \mathrm{ml}$. Sensitivity and specificity were 0.99 and 0.81 , respectively. However, this result did not fit the clinical situation, because 40 (18.9\%) of 212 patients with non-functioning pituitary adenoma were false-positive. We further analyzed patients whose serum prolactin concentration was between 90 and $200 \mathrm{ng} / \mathrm{ml}$, according to previous reports $[8,10,11]$. This range was considered as the border zone of differential diagnosis.

\section{Characteristics of patients with mild hyperprolactinemia (Table 2)}

Nine (4.2\%) patients with non-functioning pituitary adenoma and $53(55.8 \%)$ prolactinoma patients were considered as the border zone cases for differential diagnosis. Table 2 showed the summary of these them. There were no statistical differences in serum prolactin concentration $(141.3 \pm 68.2$ vs. $144.5 \pm 31.9, \mathrm{p}=0.84)$, and age (39 vs. $34, \mathrm{p}=0.12$ ). Tumor size was smaller in prolactinoma group $(22.0 \pm 6.0$ vs. $12.2 \pm 6.8, \mathrm{p}=0.01)$.

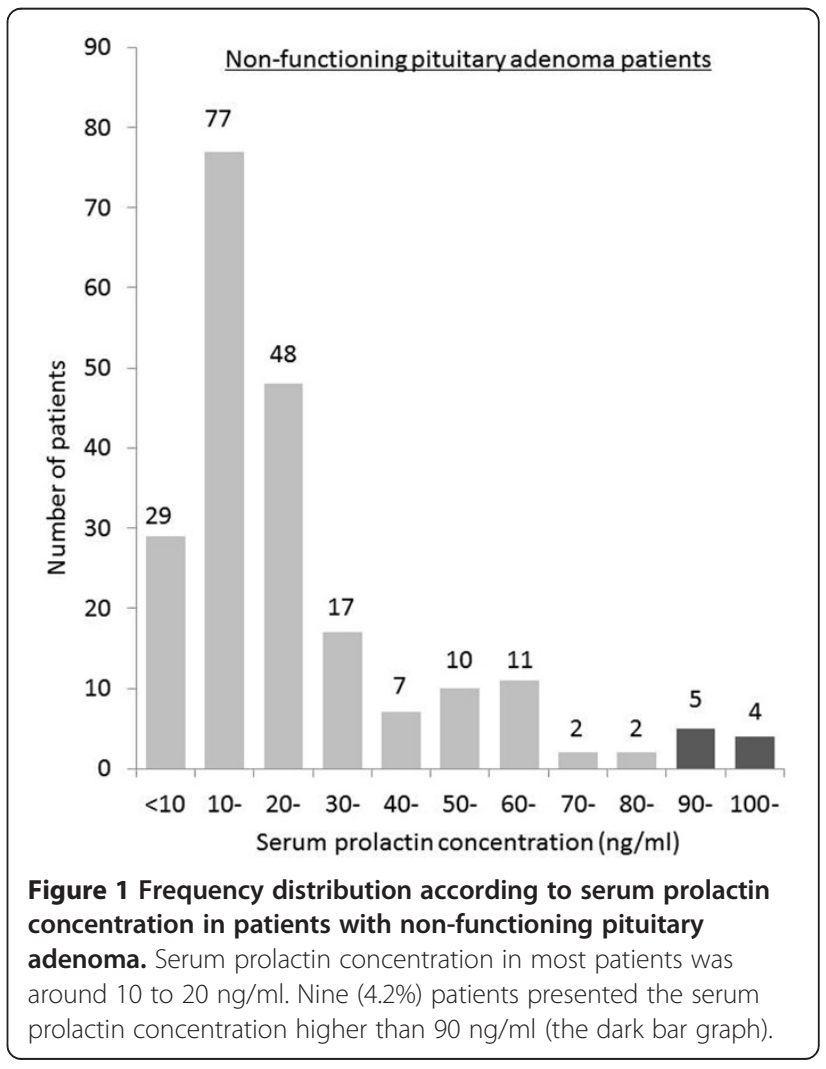




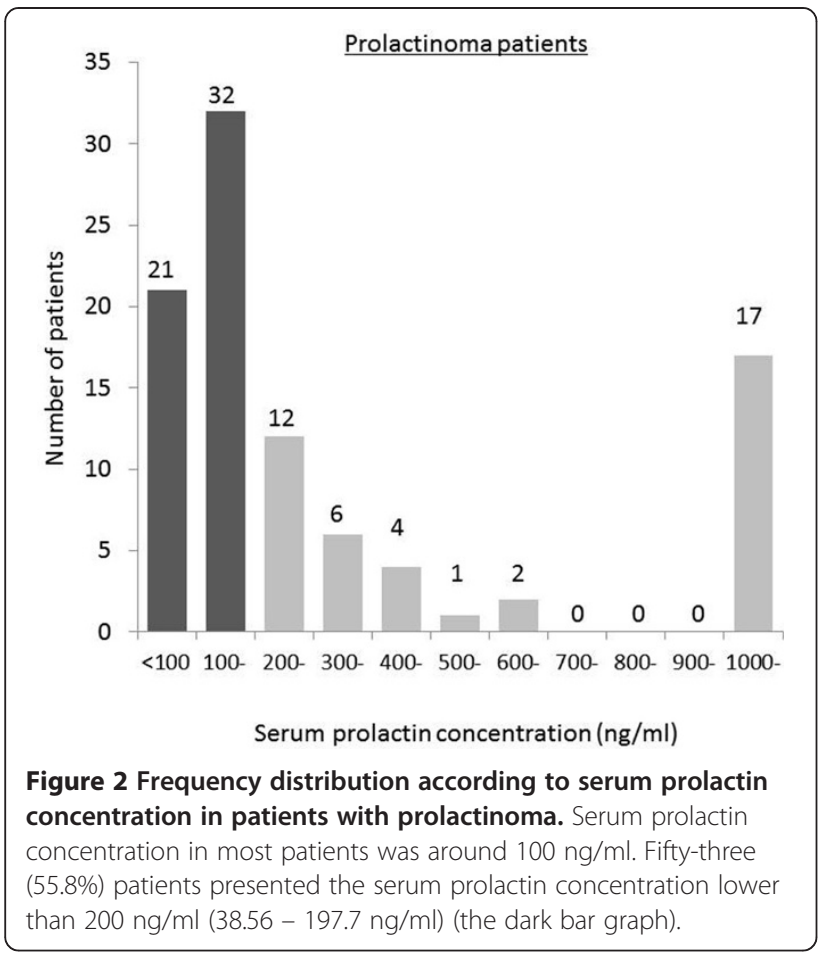

\section{Non-functioning pituitary adenoma treated with dopamine agonist}

Among the patients with non-functioning pituitary adenoma, 4 patients were initially treated with dopamine agonist. The maximum tumor diameter ranged 10 to $31 \mathrm{~mm}$. Serum prolactin concentration before medication ranged 62.41 to $130 \mathrm{ng} / \mathrm{ml}$ and was well suppressed in other 3

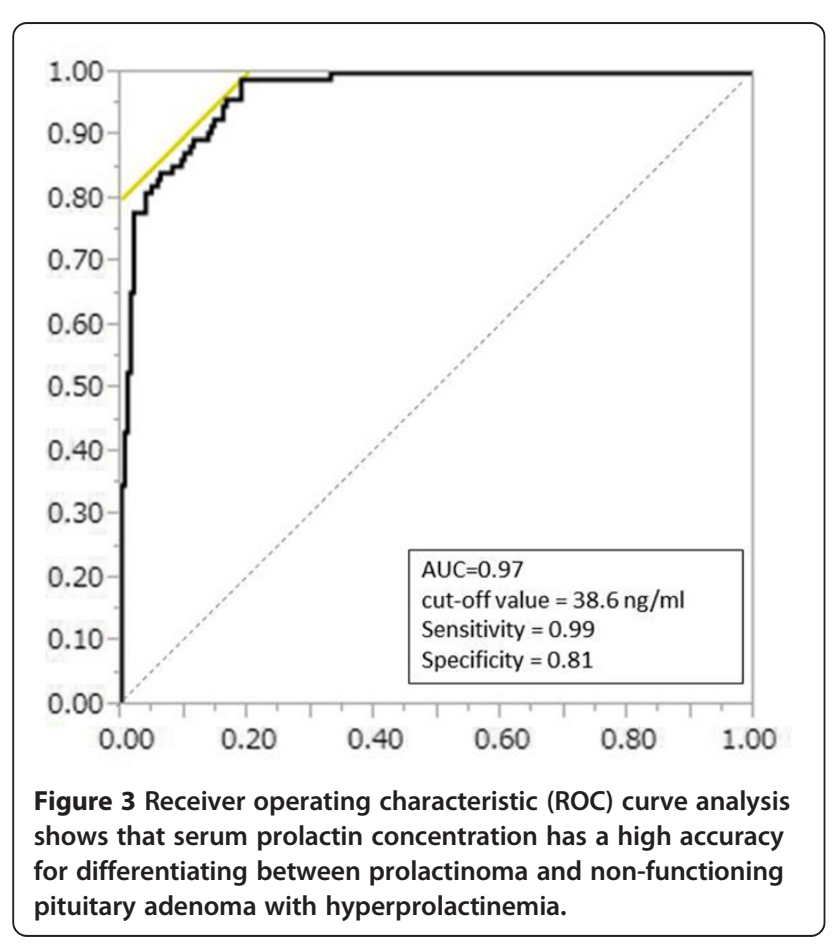

patients except for one patient who did not continue medication for some reason. All of them were followed with MR imaging every 6 months. Nevertheless, tumor shrinkage was not achieved in three patients or visual disturbance was aggravated in one patient in her clinical course.

\section{Discussion}

DAs are the first line of treatment for hyperprolactinemia, which is one of the most frequent endocrinological disorders, especially in young women. As the patients present with gonadal dysfunctions and resulted in infertility $[6,12]$, treatment for hyperprolactinemia is quite important in clinical aspect [13]. DAs have strong suppressive effects on serum prolactin level regardless of etiology, so they tend to be used for both patients with prolactinoma and non-functioning pituitary adenoma with hyperprolactinemia. The mechanism of DAs is quite specific for prolactin normalization. The agents act by binding to specific dopamine receptors on the prolactinsecreting cells, resulting in reduced synthesis and secretion of prolactin, and adenoma cell size [14]. Thus, treatment with DAs can decrease tumor size in about $90 \%$ of patients with prolactinoma [15]. In addition, the prolactin-inhibiting mechanism can affect not only adenoma cells but also normal prolactin-secreting cells. So, DAs can normalize the serum prolactin concentration in patients with non-functioning pituitary adenoma, but there is no chance for tumor regression. In clinic, patients with "high" concentration of serum prolactin are usually started treatment with DAs. In this study, we confirmed whether the serum prolactin cut-off value is reasonable to identify who should be treated with DAs.

First, we performed the ROC curve analysis to assess the cut-off value of serum prolactin concentration. This statistical analysis showed good correlation between serum prolactin level and prolactinoma diagnosis. The cutoff value was $38.6 \mathrm{ng} / \mathrm{ml}$ with acceptable sensitivity and specificity. However, this result did not fit the clinical situation, as many false-positive cases were included. Such cases have a risk of inappropriate treatment with DAs. The problem still remains to discriminate prolactinoma from non-functioning pituitary adenoma simply with serum prolactin cut-off value.

Previously, several studies have been examined the threshold of serum prolactin concentration to distinguish them. Karavitaki et al. advocated the cut-off value of serum prolactin was $94 \mathrm{ng} / \mathrm{ml}$ [8]. Other reports showed that the serum prolactin values were less than $200 \mathrm{ng} / \mathrm{ml}$ in most patients with non-functioning pituitary adenoma $[10,11]$. Compared to them, $9(4.2 \%)$ patients in our series presented the serum prolactin concentration higher than $90 \mathrm{ng} / \mathrm{ml}$ in non-functioning pituitary adeonmas, and $53(55.8 \%)$ of prolactinoma patients presented mild 
Table 2 Characteristics of patients with mild hyperprolactinemia

\begin{tabular}{|c|c|c|c|c|}
\hline \multicolumn{2}{|c|}{ Characteristic } & \multirow{2}{*}{$\begin{array}{c}\text { Non-functioning adenoma } \\
\text { (PRL >90 } \mathbf{~ n g / m l ) ~}\end{array}$} & \multirow{2}{*}{$\begin{array}{c}\begin{array}{c}\text { Prolactinoma } \\
\text { (PRL <200 ng/ml) }\end{array} \\
53\end{array}$} & \multirow{2}{*}{ P value } \\
\hline Number of patients & & & & \\
\hline Age, years old & Range (median) & $35-67(39)$ & $14-82(34)$ & 0.12 \\
\hline Tumor size & Maximum Diameter $($ mean $\pm S D, m m)$ & $22.0 \pm 6.0$ & $12.2 \pm 6.8$ & $0.01^{*}$ \\
\hline Serum prolactin concentration & (mean $\pm \mathrm{SD}, \mathrm{ng} / \mathrm{ml})$ & $141.3 \pm 68.2$ & $144.5 \pm 31.9$ & 0.84 \\
\hline
\end{tabular}

$\mathrm{PRL}=$ prolactin .

*statistically significant.

SD, standard deviation.

hyperprolactinemia less than $200 \mathrm{ng} / \mathrm{ml}$. Strict attention has to be paid for this border zone group. In our series, 4 patients with non-functioning pituitary adenoma were initially treated with dopamine agonist. All of them were in the border zone group, whose serum prolactin concentration before medication ranged 62.41 to $130 \mathrm{ng} / \mathrm{ml}$.

Taken together, the serum prolactin cut-off value is not safely applicable to establish a correct diagnosis in patients with large pituitary adenoma, nevertheless tumor size is smaller in prolactinoma than non-functioning pituitary adenoma in general population and border zone patients (Tables 1 and 2). As mentioned above, DAs were introduced to 4 patients with non-functioning pituitary adenoma for initial treatment. They showed good result of serum prolactin reduction but no effects on tumor shrinkage. As the monitoring of serum prolactin alone is not sufficient to evaluate the treatment efficacy in such cases, meticulous radiographical follow up is quite important.

Another principle is when to decide the surgical indication. Olafsdottir et al. reported that more than $90 \%$ of prolactinoma decreased in size at least 24 months treatment with dopamine agonist [16]. They also reviewed that longer usage of dopamine agonists showed with higher response rate for serum prolactin normalization and in patients with prolactinoma treated with cabergoline, 75 to $100 \%$ of prolactin normalization was achieved within 24 months. In our series, patients with nonfunctioning pituitary adenoma who were treated with dopamine agonist did not show tumor shrinkage, and surgery underwent for them 24.6 months after introduction of medication, on average. Moreover, the usage of dopamine agonists is one of the risk factors of pituitary apoplexy [17-20] and the hemorrhagic event is more frequent within 18 months since the beginning of dopamine agonist treatment [21]. Taken together, patients with hyperprolactinemia who were treated with dopamine agonist should be meticulously followed with MR imaging at least 24 months. When the neurological deterioration or no tumor shrinkage was evident, surgery should be considered.
The present study has several limitations. The patients with pituitary tumor who were successfully treated with dopamine agonist did not include because of lack of histological verification. Also, we did not assess the possibility of macroprolactinemia. However, patients without clinical symptoms were not indicated for any treatment even if the serum prolactin concentration was high, and such cases were not included in this study. More other factors such as sex and tumor size can be considered as the indicative variables for prolactinoma diagnosis. For statistical multivariate analysis, more case accumulation is required. We excluded giant adenomas, because the treatment is still challenging for this entity and outcome is still poor [22]. The treatment strategy is not well established for giant adenomas. More cases are required for better understanding of diagnostic criteria.

\section{Conclusions}

This study indicated that $4.2 \%$ of patients with hyperprolactinemia harboring non-functioning pituitary adenoma had a risk of misdiagnosis. As the serum prolactin level could not be definitive, these patients should be followed up with neuroimaging to ensure that the optimum timing for neurosurgical intervention is not missed, even if the primary purpose of gonadal restoration has been achieved with medical treatment. DAs are strong and reliable treatment for patients with hyperprolactinemia, but surgery should be considered for patients with suboptimal results following medical treatment.

\section{Ethics}

The therapeutic protocol was approved by the internal ethics committee of Kohnan Hospital 2013.

\section{Abbreviations}

FSH: Follicle-stimulating hormone; MR: Magnetic resonance; SD: Standard deviation.

\section{Competing interests}

The authors declare that they have no competing interests. 


\section{Authors' contributions}

TK analyzed the patient data regarding the endocrinological outcome, and was a major contributor in writing the manuscript. YO performed tumor removal all through the investigated period. And $\Pi$ gave an essential suggestion and supervised this manuscript. All authors read and approved the final manuscript.

\section{Author details}

'Department of Neurosurgery, Kohnan Hospital, 4-20-1 Nagamachi Minami, Taihaku-ku, Sendai, Miyagi 982-8523, Japan. ²Department of Neurosurgery, Tohoku University Graduate School of Medicine, Sendai, Miyagi, Japan.

Received: 16 December 2013 Accepted: 12 August 2014

Published: 20 August 2014

\section{References}

1. Molitch ME: Medical treatment of prolactinomas. Endocrinol Metab Clin North Am 1999, 28:143-169.

2. Pellegrini I, Rasolonjanahary $R$, Gunz $G$, Bertrand P, Delivet $C P$, Jedynak CP, Kordon C, Peillon F, Jaquet $P$, Enjalbert A: Resistance to bromocriptine in prolactinomas. J Clin Endocrinol Metab 1989, 69:500-509.

3. Knoepfelmacher M, Gomes MC, Melo ME, Mendonc a BB: Pituitary apoplexy during therapy with cabergoline in an adolescent male with prolactin-secreting macroadenoma. Pituitary 2004, 7:83-87.

4. Ikeda H, Watanabe K, Tominaga T, Yoshimoto T: Transsphenoidal microsurgical results of female patients with prolactinomas. Clin Neurol Neurosurg 2013, 115:1621-1625.

5. Ono M, Miki N, Amano K, Kawamata T, Seki T, Makino R, Takano K, Izumi S, Okada Y, Hori T: Individualized high-dose cabergoline therapy for hyperprolactinemic infertility in women with micro- and macroprolactinomas. J Clin Endocrinol Metab 2010, 95:2672-2679.

6. Hong JW, Lee MK, Kim SH, Lee EJ: Discrimination of prolactinoma from hyperprolactinemic non-functioning adenoma. Endocrine 2010 37:140-147.

7. Bevan JS, Burke CW, Esiri MM, Adams CB: Misinterpretation of prolactin levels leading to management errors in patients with sellar enlargement. Am J Med 1987, 82:29-32.

8. Karavitaki N, Thanabalasingham G, Shore HC, Trifanescu R, Ansorge O, Meston $\mathrm{N}$, Turner $\mathrm{H}$, Wass J: Do the limits of serum prolactin in disconnection hyperprolactinaemia need re-definition? A study of 226 patients with histologically verified non-functioning pituitary macroadenoma. Clin Endocrinol (Oxf) 2006, 65:524-529.

9. DeLellis AR (Ed): Pathology and Genetics of Tumours of Endocrine Organs. Lyon: IARC; 2004.

10. Klijn JG, Lamberts SW, de Jong FH, Docter R, Van Dongen KJ, Birkenhäger $J C$ : The importance of pituitary tumour size in patients with hyperprolactinaemia in relation to hormonal variables and extrasellar extension of tumour. Clin Endocrinol (Oxf) 1980, 12:341-355.

11. Smith MV, Laws ER Jr: Magnetic resonance imaging measurements of pituitary stalk compression and deviation in patients with nonprolactinsecreting intrasellar and parasellar tumors: lack of correlation with serum prolactin levels. Neurosurgery 1994, 34:834-839.

12. Mancini T, Casanueva FF, Giustina A: Hyperprolactinemia and prolactinomas. Endocrinol Metab Clin North Am 2008, 37:67-99.

13. Fishel S, Dowell K, Thornton S: Reproductive possibilities of infertile couples: present and future. In Infertility in the Modern World: Present and Future Prospects. Edited by Bentley GR, Mascie-Taylor CGN. Cambridge: Cambridge University Press; 2000:17-41.

14. Unuane D, Tournaye $H$, Velkeniers B, Poppe K: Endocrine disorders \& female infertility. Best Pract Res Clin Endocrinol Metab 2011, 25:861-873.

15. Colao A, Di Sarno A, Landi ML, Scavuzzo F, Cappabianca P, Pivonello R, Volpe R, Di Salle F, Cirillo S, Annunziato L, Lombardi G: Macroprolactinoma shrinkage during cabergoline treatment is greater in naive patients than in patients pretreated with other dopamine agonists: a prospective study in 110 patients. J Clin Endocrinol Metab 2000, 85:2247-2252.

16. Olafsdottir A, Schlechte J: Management of resistant prolactinomas. Nat Clin Pract Endocrinol Metab 2006, 2:552-561.

17. Arafah BM, Taylor HC, Salazar R, Saadi H, Selman WR: Apoplexy of a pituitary adenoma after dynamic testing with gonadotropin-releasing hormone. Am J Med 1989, 87:103-105.
18. Holness RO, Ogundimu FA, Langille RA: Pituitary apoplexy following closed head trauma. Case report. J Neurosurg 1983, 59:677-679.

19. Onesti ST, Wisniewski T, Post KD: Clinical versus subclinical pituitary apoplexy: presentation, surgical management, and outcome in 21 patients. Neurosurgery 1990, 26:980-986.

20. Pliam MB, Cohen M, Cheng L, Spaenle M, Bronstein MH, Atkin TW: Pituitary adenomas complicating cardiac surgery: summary and review of 11 cases. J Card Surg 1995, 10:125-132.

21. Carija R, Vucina D: Frequency of pituitary tumor apoplexy during treatment of prolactinomas with dopamine agonists: a systematic review. CNS Neurol Disord Drug Targets 2012, 11:1012-1014.

22. Goel A: Challenge of giant pituitary tumors. World Neurosurg 2013. (epub ahead) doi:10.1016/j.wneu.2013.10.014.

doi:10.1186/1756-0500-7-555

Cite this article as: Kawaguchi et al:: Diagnostic pitfalls of hyperprolactinemia: the importance of sequential pituitary imaging. BMC Research Notes 2014 7:555

\section{Submit your next manuscript to BioMed Central and take full advantage of:}

- Convenient online submission

- Thorough peer review

- No space constraints or color figure charges

- Immediate publication on acceptance

- Inclusion in PubMed, CAS, Scopus and Google Scholar

- Research which is freely available for redistribution

Submit your manuscript at www.biomedcentral.com/submit
C) Biomed Central 